Алла ВЕЛІХОВСЬКА,

orcid.org/0000-0002-8405-3075

кандидат педагогічних наук, доиент,

доиент кафедри методики професійного навчання

Миколаївського національного аграрного університету

(Миколаїв, Україна) velih@ukr.net

\title{
МЕТОДОЛОГІЧНІ ОСНОВИ ФОРМУВАННЯ ЕМОЦЙНОГО ІНТЕЛЕКТУ МАЙБУТНІХ ІНЖЕНЕРІВ-ЕНЕРГЕТИКІВ В УМОВАХ ЇХНЬОЇ ПРОФЕСІЙНОӤ ПІДГОТОВКИ, РОЗВИТКУ ПРОФЕСІЙНИХ КОМПЕТЕНТНОСТЕЙ
}

\begin{abstract}
Аналіз тенденцій сучасного стану економічного розвитку України, ринку й умов праці, які постійно змінюються, виявили проблему наявності відповідного рівня емоційного інтелекту у майбутніх інженерів-енергетиків. Для вивчення иієї проблеми були опрацьовані моделі емоційного інтелекту за двома напрямами: як сукупність компонентів, які об'єднують різні психічні феномени за змішаною моделлю; як система здатностей (Д. Гоулмана, Д. Мейера, Дж. Меттьюса, П. Селовея, Р. Бар-Она, Р. Робертса, Д. Люсина, М. Манойлова), проведено категоріальний аналіз термінів «емоиійний інтелект», «емоиійна компетентність», виявлені подібності й відмінності, які дозволяють стверджувати, щзо достатній рівень сформованості емоційного інтелекту дозволяє вибудовувати ефективну взаємодію працівників енергетичної сфери у прочесі виконання їхніх професійних обов'язків і входить до складу сукупностей компетенцій як одного зі складників професійної компетениї. Найкращі результати у побудові кар'єри приносить відповідний рівень розвитку емоційного інтелекту у поєднанні глибоких професійних знань із потужною мотивацією.

У статті представлено досвід навчання здобувачів вищої освіти інженерно-енергетичного факультету Миколаївського національного аграрного університету за авторською програмою розвитку емочійного інтелекту майбутніх інженерів під час їхнього професійного навчання иляхом організачії иілеспрямованої зовнішньої дії (активних форм навчання) на розвиток кожного з чотирьох складників (автори А. Б. Веліховська, В. М. Курепін) при викладанні дисииллін суспільно-гуманітарного напряму; умови забезпечення якості реалізації програми та найбільш ефективні стратегії ї̈ реалізації; форми і методи, зокрема нестандартні, проведення практичних занять; труднощчі та проблеми реалізації; основні аспекти формування навичок ефективної взаємодії у колективі, здатність працювати в команді, висока адаптивність до соиіальних ситуацій, які постійно змінюються; техніки тренування когнітивного мислення.

Результати роботи за програмою, представленою авторами, дозволяють обгрунтувати можливість формування емоиійного інтелекту в рамках моделі когнітивних здатностей, а також відкривають нові можливості для формування емоційної компетентності в теоретичному і практичному планах, вирішувати питання підготовки майбутніх інженерів-енергетиків до роботи в нових умовах.
\end{abstract}

Ключові слова: емочійний інтелект, емоційна компетентність, емочія, здатність, ідентифікація емоцій, керування емоціями.

Alla VELIKHOVSKA, orcid.org/0000-0002-8405-3075 Candidate of Pedagogical Sciences, Associate Professor, Associate Professor at the Department of Vocational Training Methods Mykolayiv National Agrarian University (Mykolaiv, Ukraine)velih@ukr.net

\section{METHODOLOGICAL BASES OF FORMATION OF INTELLIGENCE OF FUTURE POWER ENGENEERS IN THE CONDITIONS OF PROFESSIONAL TRAINING, DEVELIPMENT OF PROFESSIONAL COMPETENCES}

\footnotetext{
Analysis of the current state of economic development of Ukraine, the market and working conditions, which are constantly changing, revealed the problem of having the appropriate level of emotional intelligence in future energy engineers. To study this problem, models of emotional intelligence were developed in two directions: as a set of components that combine different mental phenomena in a mixed model; as a system of abilities (D. Goleman, D. Meyer, J. Matthews, P. Selovey, R. Bar-On, R. Roberts, D. Lusin, M. Manoilov), a categorical analysis of the terms "emotional intelligence", "emotional competence", identified similarities and differences that suggest that a sufficient level of emotional intelligence allows you to build effective interaction of energy workers in the performance of their professional duties and is part of a
} 
set of competencies as one of the components of professional competence. The best results in career building are brought by the corresponding level of development of emotional intelligence in combination of deep professional knowledge with strong motivation.

The article presents the experience of higher education students of the Faculty of Engineering and Energy of Mykolayiv National Agrarian University on the author's program of emotional intelligence of future engineers in the course of their professional training by organizing targeted external action (active forms of learning) for the development of each of the four components (authors A. B. Velikhovska, V. M. Kurepin) in teaching social sciences and humanities; conditions for ensuring the quality of program implementation and the most effective strategies for its implementation; forms and methods, in particular non-standard, conducting practical classes; difficulties and problems of implementation; main aspects of the formation of skills of effective interaction in the team, the ability to work in a team, high adaptability to constantly changing social situations; cognitive thinking training techniques.

The results of the program presented by the authors allow to substantiate the possibility of forming emotional intelligence within the model of cognitive abilities, as well as open new opportunities for the formation of emotional competence in theoretical and practical terms, to address future engineers to work in new conditions.

Key words: emotional intelligence, emotional competence, emotion, ability, emotion identification, emotion management.

Постановка проблеми. Надійне енергозабезпечення $є$ одним із основних стратегічних пріоритетів у XXI столітті, найважливішою умовою функціонування усіх сфер економіки країн світу. Україна не є винятком, тому розвиток енергетичної галузі розглядається як шлях до економічної незалежності країни.

Стрімкий розвиток технологій спричинив зміни як у концепції розвитку країни, так і в концепції розвитку освіти, зокрема підготовки майбутніх інженерів-енергетиків. На перше місце виходить необхідність підготувати фахівців, здатних працювати в епоху змін, стрімкого розвитку технологій, зміни концепцій і пріоритетів. Підготовка таких працівників цілком лягає на плечі закладів вищої освіти України.

В сучасних економічних умовах перед компаніями особливої гостроти набула проблема залучення i утримання висококваліфікованих працівників. Найбільш актуальним при відборі i професійному зростанні співробітників стає виявлення і розвиток у кандидатів і працівників навичок до ефективної взаємодії у колективі, здатність працювати в команді, висока адаптивність до соціальних ситуацій, які постійно змінюються. Перелічені навички є складниками емоційної компетенції працівників [9]. Однією 3 умов готовності майбутнього інженера-енергетика до роботи в сучасних компаніях $\epsilon$ наявність високого рівня сформованості емоційного інтелекту (далі - EQ).

Мета статті - розгляд методологічних основ формування емоційного інтелекту майбутніх інженерів-енергетиків в умовах їх професійного навчання.

Математиці, мові, мистецтву навчають із дитинства, в той час як науці керування власними емоціями не приділяли достатньої уваги. Тривалий час вважалося, що емоційна сфера $є$ чимось ірраціональним, такою, яка не піддається жодним пра- вилам і тому іï не можна сформувати. Проте професійний успіх людини на $85 \%$ залежить від soft skills («м'яких» людських навичок, які належать до сфери EQ) і лише на 15\% - від hard skills (технічних, професійних навичок). «Дуже важливо розуміти, що EQ - це не противага інтелекту, це не тріумф серця над головою - це єдиний шлях перетину обох», - зазначав у своїх працях Девід Р. Карузо, психолог, професор кафедри психології Сльського університету, співавтор концепції ЕQ [13].

Поняття емоційного інтелекту EQ увів клінічний фізіолог Рувен Бар-Он у 1985 році. У 1996 році він презентував учасникам зборів американської асоціації психологів у Торонто свій тест EQ-i (Emotional Quotient Inventory), який містив перелік питань для визначення коефіцієнту емоційного інтелекту. Популярність теорії розвитку емоційного інтелекту (далі - EQ) в сучасному світі зумовлена тим, що змістові характеристики EQ є фактором особистісного і професійного розвитку, які впливають на успішність життєдіяльності на різних вікових етапах.

Аналіз досліджень. Проблема EQ у працях зарубіжних вчених розглядається у двох напрямах: 1) дослідження EQ як сукупності компонентів, що об'єднують різні психічні феномени за змішаною моделлю (Р. Бар-Он, Д. Гоулман, Р. Бояцис, К. Петрідес) [12; 13]; 2) як система здатностей особистості (Дж. Мейєр, П. Соловей, Д. Карузо) [10; 11]. Система, запропонована цими науковцями, включає такі компоненти: сприйняття, ідентифікація емоцій, їх вияв; управління власними емоціями та емоціями інших осіб; використання емоцій для вирішення завдань, зокрема фасилітації мислення; розуміння й аналіз емоцій.

У 1995 році, продовжуючи вдосконалювати власну теорію, Д. Гоулман [2] виділив такі аспекти EQ: самосвідомість, самоврядування, соціальна поінформованість, управління взаємовідносинами. 
На відміну від нього, Р. Бар-Он запропонував виділяти п'ять сфер компетентностей, кожна 3 яких включає такі субкомпоненти: пізнання себе (впевненість; усвідомлення і прийняття власних емоцій, самоповага, самоактуалізація, незалежність); навички спілкування (емпатія, соціальна відповідальність, міжособистісні взаємини); адаптивність (виявлення і вирішення проблем, реальне бачення суті, гнучкість); стресостійкість (стійкість, самоконтроль, вміння миттєво приймати рішення); оптимізм. Ми розуміємо EQ як здатність усвідомлювати й керувати власними емоціями, вміння розуміти емоції інших, впливати на них та маніпулювати ними.

У своїх наукових працях Д. Люсіна та М. Манойлова [6] розглядають EQ з урахуванням внутрішньо- $\mathrm{i}$ міжособистісних аспектів, які містять здатності до розуміння і управління чужими і власними емоціями. Внутрішньо-особистісний аспект містить усвідомлення власних почуттів; самооцінку, самовпевненість, гнучкість, адаптивність, оптимізм, самоконтроль, зацікавленість, новаторство, мотивацію. До міжособистісного аспекту входять комунікативність, відкритість, емпатія, здатність враховувати й розвивати інтереси іншої людини, взаємоповага, корпоративність. В якості основних характеристик виділяють такі 3 них: емпатія, толерантність, асертивність і самооцінка.

Проведений теоретичний аналіз дозволив констатувати наявність різних підходів до визначення змістових характеристик i створення моделей, які описують взаємозв'язок і взаємозумовленість [5]. Тому ми розглядатимемо $\mathrm{EQ}$ як поєднання когнітивного, регулятивного і поведінкового компонентів.

Виклад основного матеріалу. Нині більшість компаній працює над тим, щоб забезпечити глобальну закупку, глобальний продаж, глобальну оплату, глобальну доставку і глобальні мандрівки для усіх. Професія інженера-енергетика не передбачає концентрацію на людині, людських стосунках. В основу професійної діяльності покладено «справу» (предмет, річ, технологічний процес), всі міжособові стосунки опосередковані «справою». Це потребує високого рівня сформованості як професійних, зокрема технічних, здатностей, так й інтелектуальних.

Доведено, що від емоційного стану фахівця дуже залежить і продукт його професійної діяльності [1]. Оскільки професійний розвиток, кар'єра інженера залежить від успішної взаємодії із соціальним середовищем, то це потребує не лише сформованих когнітивних здібностей, а й достатнього рівня сформованості EQ, особливо коли профе- сійнапредметнадіяльність інженера починає доповнюватися спілкуванням із колегами, підлеглими, керівництвом, аудиторами, замовниками [3].

Протягом трьох років у Миколаївському національному аграрному університеті кафедрою методики професійного навчання здійснюється навчання за програмою формування EQ у майбутніх інженерів, зокрема енергетичної сфери (далі Програма). Більшість досліджень, спрямованих на пошук шляхів розвитку EQ у дітей і дорослих, підтверджує можливість формування EQ під час навчання. Проте інтерес викликає питання стабільності отриманих результатів у довгострокової практиці. Особливо у контексті, коли EQ розглядається як поєднання здатностей [4]. На нашу думку, потребує вивчення питання змісту, структури, стратегії ефективності програм розвитку EQ.

Враховуючи, що реалізація окремої програми розвитку EQ у системі вищої освіти потребує додаткового часу, який не передбачено програмою, було вирішено розробити програму формування EQ у майбутніх інженерів-енергетиків при вивченні дисциплін гуманітарного спрямування. 3 метою забезпечення якості реалізації програми:

- щорічно проводиться вступне i вихідне анкетування студентів 3 метою діагностики рівня сформованості EQ;

- розроблено інструментарій вимірювання рівня сформованості EQ;

- презентовано досвід професорсько-викладацького складу кафедри щодо форм і методів формування EQ, які доцільно використовувати під час навчання дисциплінам гуманітарного спрямування;

- оприлюднено проміжні результати реалізації програми у наукових фахових журналах;

- підготовлено рекомендації щодо розробки тематики і структури занять для майбутніх інженерів-енергетиків з урахуванням специфіки формування EQ.

За результатами програми формування EQ можна виокремити найбільш ефективні стратегії iї реалізації:

- наукова основа, на якій базується Програма;

- зворотній зв'язок, індивідуальна підтримка, розробка індивідуального плану розвитку;

- групи підтримки, сформовані навколо теми саморозвитку, регулярні консультації з викладачами протягом навчання;

- підтримка учасників Програми;

- ведення щоденника емоцій.

Якщо розглядати EQ як суму навичок, то нині виділяють чотири такі категорії. Перша категорія включає в себе вміння ясно і зрозуміло спілкува- 
тися з іншими, пояснити очікування, активно слухати, впливати і надихати, працювати в команді або бути у ній керівником, злагоджувати або уникати конфліктів. Друга категорія - це загальна емпатія і комфортне самопочуття у великій групі людей. Незалежно від того, екстраверт така особа чи інтроверт, вона відчуває емоційні сигнали інших, уникаючи непорозуміння. Третя категорія - знання своїх слабких і сильних сторін, комфортне існування $з$ ними, а також позитивний вплив на життя. Четверта - вміння керувати власними емоціями, обмежувати їх руйнівний вплив на особу, здатність виконувати взяті на себе обов'язки, підтримувати довгострокові стосунки і змінюватися відповідно до середовища.

Проаналізувавши першоджерела $\mathrm{i}$ роботи сучасних вчених, ми дійшли висновку, що EQ це сума навиків і здібностей людини розпізнавати емоції, розуміти наміри, мотивацію і бажання інших людей і свої власні, керувати власними емоціями і емоціями інших людей 3 метою вирішення практичних завдань. EQ у широкому розумінні - це визнання за собою й іншими права на почуття (як позитивні, так і негативні), вміння розрізняти власні почуття від «голих» фактів, відчувати настрій і наміри спілкування з людьми.

Важливою часткою емоційного інтелекту можна вважати вміння розпізнавати і чітко описувати власні емоції, не піддаватися паніці, трансформувати негативні, руйнівні емоції (страх, гнів, сум, ревнощі, заздрість) у позитивні, широко використовувати емоційну мову з Я-повідомленнями. Високий рівень сформованості EQ впливає на вміння розпізнавати емоції інших. Це дає змогу вносити зміни у процес спілкування і взаємодії. Керівник, який розуміє емоції підлеглих, надає їм інструменти для зростання й розвитку, виявляє себе як емпатний лідер, тому що відчуває запити інших і допомагає їм реалізовувати свій потенціал.

Ми виявили такі техніки тренування когнітивного мислення:

1. Підвищення пізнавальної цікавості.

2. Потреба у покращенні: абстрагування; пошуки асоціацій; операції з проведення творчої дедукції (дедуктивне мислення); операції індуктивного мислення (проведення аналогій); метафоричне мислення; здійснення перетворень.

Аналіз проміжних результатів експерименту засвідчив, що ефективність практичних занять підвищується, якщо зміст було розроблено відповідно до забезпечення вимог: інтегрований зміст навчання; зміст заняття пов'язаний із реальністю; практична цінність інформації підтверджується через реальні факти у змодельованих на заняттях ситуаціях. Навчальні методи були доповнені такими, що спонукають здобувачів вищої освіти бути ініціативними, активними, комунікабельними, відповідальними, передбачливими. Ефективність занять підвищується через нестандартні форми роботи на занятті; інтерактивні методи; проектні технології; методи змішаного навчання; вихід за межі навчальної аудиторії; «когнітивні гачки» та звернення до досвіду студентів; відповідні форми оцінювання.

EQ тісно пов'язаний із мотивацією і проактивною поведінкою - вмінням адекватно реагувати на зміни, поєднувати людей, представляти їхні інтереси, делегувати владу і вселяти упевненість в інших. Ми можемо назвати п'ять основних вимог до ефективності Програми формування EQ:

- інтерес і мотивація до навчання;

- тривалість навчання;

- організація навчання в режимі постійної підтримки;

- наявність постійної практики використання навичок, отриманих у процесі навчання в особистій і професійній сферах діяльності;

- підтримка з боку інших учасників навчання.

Для діагностики рівня сформованості $\mathrm{EQ}$ серед майбутніх інженерів-енергетиків ми використовували тести, розроблені к.пед.н., доцентом А. Б. Веліховською і ст. викладачем кафедри методики професійного навчання В. М. Курепіним на основі теоретичної моделі EQ як здібності Дж. Мейєра, П. Селовея і Д. Карузо, опитувальник MSCEIT. Результати засвідчили, що учасники навчання мають середнє значення загального $\mathrm{EQ}$, а також його основних шкал. Вони знахо-

Показники складників емоційного інтелекту

\begin{tabular}{|c|c|c|c|c|c|c|c|c|c|c|}
\hline \multirow[t]{2}{*}{ Рівень EQ } & \multicolumn{2}{|c|}{$\begin{array}{c}\text { Емоційна } \\
\text { обізнаність }\end{array}$} & \multicolumn{2}{|c|}{$\begin{array}{l}\text { Керування } \\
\text { емоціями }\end{array}$} & \multicolumn{2}{|c|}{ Самомотивація } & \multicolumn{2}{|c|}{ Емпатія } & \multicolumn{2}{|c|}{$\begin{array}{c}\text { Розпізнавання } \\
\text { емоцій інших } \\
\text { людей } \\
\end{array}$} \\
\hline & $\mathbf{I}$ & II & I & II & I & II & I & II & I & II \\
\hline Високий & $9,5 \%$ & $12,25 \%$ & - & $1,5 \%$ & $31 \%$ & $37,25 \%$ & - & $2 \%$ & $6,5 \%$ & $18,75 \%$ \\
\hline Середній & $58,5 \%$ & $56,5 \%$ & $39 \%$ & $55,5 \%$ & $50,5 \%$ & $56,25 \%$ & $45,25 \%$ & $50 \%$ & $41,5 \%$ & $37,5 \%$ \\
\hline Низький & $32 \%$ & $31,25 \%$ & $61 \%$ & $43 \%$ & $18,5 \%$ & $6,25 \%$ & $54,75 \%$ & $48 \%$ & $52 \%$ & $43,75 \%$ \\
\hline
\end{tabular}


дяться на середньому рівні сформованості - на рівні «компетентності». Найбільш високі показники спостерігаються за шкалою «Керування емоціями» $(\mathrm{M}=103,41)$. Дещо менші показники характеризують шкалу «Використання емоцій» $(\mathrm{M}=94,23)$. Для $67 \%$ респондентів характерним $є$ середній рівень розвитку здатності розуміти емоції і керувати ними, 54,92\% студентів, які брали участь в опитуванні, мають високий рівень здатності сприймати й ідентифікувати свої емоції та емоції інших; 37,67\% - низький рівень використання емоцій для вирішення професійних завдань і в особистому житті.

Для дослідження відмінностей у структурі інтелекту між студентами першого та другого курсу ми використовували методику Н. Хоппа «Оцінка емоційного інтелекту». Результати наведено у табл. 1.

Формування емоційного інтелекту відбувається відповідно до розробленої автором спеціалізованої програми, в основу якої закладено активні методи навчання. Отримані результати засвідчили результативність і ефективність програми. У майбутніх інженерів-енергетиків була позитивна динаміка щодо підвищення рівня розвитку емпатії, комунікативної компетентності, контролю і керування емоціями, загального рівня емоційного інтелекту.
Формування емоційного інтелекту відбувається через розвиток його основних чинників - драйверів. Тому необхідно розвивати саме їx. Саморегуляція, вміння почути і ставити себе на місце іншої людини, здатність керувати емоційним станом доповнює практичні навички й уміння в усіх сферах, в яких необхідне спілкування. Найкращі результати у побудові кар'єри приносить EQ у поєднанні глибоких професійних знань із потужною мотивацією. Дійсно, високий коефіцієнт інтелекту (IQ) допомагає вступити в університет і отримати довгоочікувану роботу, проте саме EQ впливає на стресостійкість, самовідчуття у робочому колективі, рівень пристосування до турбулентності робочої ситуації.

Висновки. Походження, спадковість і освіта впливають на самореалізацію людини у дорослому житті. Проте своїй успішності вона завдячує унікальному поєднанню інтелектуальних здібностей і емоційної чутливості, коли власні почуття й бажання людина використовує не дискретно або деструктивно, а для досягнення довгострокових цілей. Саме вміння людини керувати своїми почуттями і розпізнавати почуття інших впливає на іiі здатність вибудовувати довготривалі стосунки як у бізнесі, так і в особистому житті, бути впливовою, очолювати колектив, товаришувати, створювати родину.

\section{СПИСОК ВИКОРИСТАНИХ ДЖЕРЕЛ}

1. Балакирева Е. И. Профессиональная компетентность: сущностные характеристики и условия развития. Т. 5 . / Е. И. Балакирева, А. В. Малышева, Е. Ю. Коновалова. Балтийский гуманитарный журнал. Калининград : ВИНИТИ, 2016. № 4. С. 154-158.

2. Гоулман Д. Эмоциональное лидерство: искусство управлять людьми на основе эмоционального интеллекта; пер. с англ. 4-е изд. / Д. Гоулман, Р. Бояцис, Э. Макки. М. : Альпина Паблишерз, 2010. 301 с.

3. Зарицька В. В. Необхідність розвитку емоційного інтелекту особистості у процесі їі підготовки до професійної діяльності. Вісник Одеського національного університету. Одеса : ОНУ, 2010. № 16. С. 13-24.

4. Кошонько Г. А. Розвиток емоційного інтелекту студентів-психологів. Збірник наукових праць Національної академії Державної прикордонної служби Украӥни. Серія: Педагогічні та психологічні науки. 2013. № 4. С. 341-350. URL: http://nbuv.gov.ua/UJRN/znpnapv_ppn_2013_4_36.

5. Леонтьев О. М. Потребности, мотиви и эмоции. М. : МГУ, 2007. 246 с.

6. Сергиенко Е. А. Тест Дж. Мэйера, П. Сэловея и Д. Карузо «Эмоциональный интеллект» (MSCEIT v.2.0): Руководство. / Е. А. Сергиенко, И. И. Ветрова. М. : Институт психологии РАН, 2010. 176 с.

7. Шевцова О. М. Психологічний супровід професійно-особистісного розвитку вчителя в умовах інноваційної діяльності : наук.-метод. посіб. / О. М. Шевцова. К. : КУ ім. Бориса Грінченка, 2015. 128 с.

8. Юсупова Г. В. Коэффициент эмоциональности как условие успешности в бизнесе. Балтийский гуманитарный журнал. Калининград : ВИНИТИ, 2014. № 1. С. 76-79.

9. Cherniss C. Successful Strategies for Developing Emotional Intelligence in the Workplace. Book of abstract: 4th International Congress on Emotional Intelligence, New-York City, USA, 2013. P. 8.

10. Clarke N. Developing Emotional Intelligence Abilities Through Team-Based Learning. Human Resource Development Quarterly. Vol. 21, № 2. 2010. P. 119-138.

11. Ciarrochi J., Mayer J. D. Applying emotional intelligence. A practitioner's guide. New-York : Psychology Press, 2007. 184 p.

12. Mayer J. D., Salovey P., Caruso D. R. Models of emotional intelligence. Handbook of human intelligence; (2nd ed.)/ R. J. Sternberg (ed.). New-York : Cambridge University Press, 2000. P. 396-422. 


\section{REFERENCES}

1. Balakireva E. I. Professionslnaya kompetentnoct: sushnostnie harakterystiki I usloviya rozvitiya. [Professional competence: essential characteristics and conditions for development] T. 5 / E. I. Balakireva, A. V. Malycheva, E. Y. Konovalova. Baltiyskiy gumanitarniy jurnal. Kaliningrad : VINITI, 2016, № 4. P. 154-158 [in Russian].

2. Goulman D. Emotcionalnoe liderstvo: iskusstvo upravlat ludmi na osnove emotcionalnogo intellekta [Emotional Leadership: The Art of Managing People Based on Emotional Intelligence]. M. : Alpina Publishers, 2010. 301 p. [in Russian].

3. Zarytska V. V. Neobhidnist rozvitku emotciynogo intelektu osobistosty v protcesi ii pidgotovky do profesiynoyi diyalnosty [The need to develop the emotional intelligence of the individual in the process of its preparation for professional activity] / V. V. Zarytska. Visnik Odeskogo Natcionalnogo Universitety. Odesa : ONU. 2010. № 16. P. $13-24$.

4. Koshonko G. A. Rozvitok emotciynogo intelektu studentyv-psihologiv [Development of emotional intelligence of students-psychologists] / G. A. Koshonko. Zbirnyk naukovih pratc Natcionalnoyi akademiyi Derjavnoyi prikordonoyi slugbi Ukraini. 2013. № 4. P. 341-350. http://nbuv.gov.ua/UJRN/znpnapv_ppn_2013_4_36.

5. Leontiev O. M. Potrebnosti, motivi i emotcii [Needs, motives and emotions] / O. M. Leontiev. Moskva : MGU, 2007. 246 p. [in Russian].

6. Sergienko E. A. Test J. Meyer, P. Saloway and D. Caruso "Emotcionalniy intellekt" (MSCEIT v.2.0): rukovodstvo. [Test J. Mayer, P. Salovey and D. Caruso "Emotional Intelligence” (MSCEIT v.2.0): Manual.] / E. A. Sergienko, I. I. Vetrova. Moskva : Institut Psihologii, RAN, 2010. 176 p. [in Russian].

7. Shevtsova O. M. Psyhologichniy suprovid profesiyno-osobistisnogo rozvitku vchitelya v umovah innovatciynoyi diyalnosty : nauk.-metod. posyb. [Psychological support of professional and personal development of a teacher in the conditions of innovative activity] / O. M. Shevtsova. Kyiv : KU im. Borysa Hrinchenko, 2015. 128 p.

8. Yusupova G. V. Coefficient emotionalnosty kak usloviye uspechnosty v biznese [Emotionality coefficient as a condition for business success]. Baltiyskiy gumanitarniy jurnal. Kaliningrad : VINITI, 2014. № 1. P. 76 -79 [in Russian].

9. Cherniss C. Successful Strategies for Developing Emotional Intelligence in the Workplace. Book of abstract: 4th International Congress on Emotional Intelligence, New-York City, USA, 2013. 8 p.

10. Clarke N. Developing Emotional Intelligence Abilities Through Team-Based Learning. Human Resource Development Quarterly. Vol. 21, № 2. 2010. P. 119-138.

11. Ciarrochi J., Mayer J. D. Applying emotional intelligence. A practitioner's guide. New-York : Psychology Press, 2007. 184 p.

12. Mayer J. D., Salovey P., Caruso D. R. Models of emotional intelligence // Handbook of human intelligence; (2nd ed.) / R. J. Sternberg (ed.). New-York : Cambridge University Press, 2000. P. 396-422. 